\title{
O PROTAGONISMO INFANTIL POR MEIO DA RESISTÊNCIA EM KAMCHATKA (2003)
}

\author{
Keyla Andrea Santiago Oliveira ${ }^{1}$, Pollyanna Rosa Ribeiro ${ }^{2}$ \\ ${ }^{1}$ Doutora em Educação pela Universidade Federal de Goiás - UFG. Docente do Programa de Pós-Graduação em \\ Educação da Universidade Estadual de Mato Grosso do Sul - UEMS, Campo Grande-MS. E-mail: \\ keylaandrea@yahoo.com.br \\ ${ }^{2}$ Mestre em Educação pela Universidade Federal de Goiás - UFG. É professora efetiva da PUCGO e coordenadora \\ pedagógica do Centro Municipal de Educação Infantil (CMEI) Cecília Meireles na rede pública de Goiânia
}

\section{RESUMO}

Nosso pressuposto é que o cinema e seus dispositivos estéticos podem revelar sutilezas que o cotidiano tão imediatista muitas vezes não nos permite: o olhar da criança sobre o mundo e seus dramas inerentes à infância. E o que podemos acessar sobre as aflições infantis diante do controle social regido pela centralização do poder nos militares e pela perda dos direitos? A proposta deste trabalho é empreender uma discussão sobre a leitura da criança em um contexto social vulnerável por meio do filme argentino Kamchatka (2003) e sua potência enquanto ser de resistência. É sob a ótica do protagonista de 10 anos de idade, Matías (Harry), que acompanhamos a confluência da tensão, da ludicidade e também do enigma da resistência que os pais vivenciam diante da ditadura. Este artigo é ligado à pesquisa interinstitucional em andamento Arte, psicanálise e educação: procedimentos estéticos no cinema e as vicissitudes da infância CEPAE/ UFG/PUCGO/ UEG/UAB-UNB/UEMS, tem como metodologia de investigação a análise fílmica e toma como referencial teórico Adorno e Horkheimer (1985), Adorno (1992), Bernadet (1985), Bordwell (2013), Gardies (2006), Rojas (2014) e Truffaut (2005). Os resultados levantados apontam para a vigorosidade da obra fílmica ao descortinar o impacto da penetração imperativa da barbárie da ditadura nos diversos meandros sociais, em especial, na vida infantil.

Palavras-chave: Cinema. Educação. Vulnerabilidade. Protagonismo Infantil.

\section{CHILD PROTAGONISM THROUGH RESISTANCE IN KAMCHATKA (2003)}

\begin{abstract}
Our assumption is that cinema and its aesthetic devices can reveal subtleties that the daily life so often does not allow us: the child's look on the world and its inherent dramas of childhood. And what can we access about childish afflictions in the face of social control governed by the centralization of power in the military and by the loss of rights? The proposal of this work is to develop a discussion about the reading of the child in a vulnerable social context through the Argentinean film Kamchatka (2003). It shows the power of child resistance. It is from the perspective of the 10 -year-old protagonist, Matías (Harry), who accompanies the confluence of tension, playfulness and also the enigma of resistance that parents experience before the dictatorship. This article is linked to the research ...,it has as a research methodology the filmic analysis and takes as theoretical reference Adorno and Horkheimer (1985), Adorno (1992), Bernadet (1985), Bordwell (2013), Gardies, Rojas (2014), Truffaut (2005). The results point to the vigor of the filmic work by unveiling the impact of the imperative penetration of barbarism of the dictatorship in the various social intricacies, especially in children lives.
\end{abstract}

Keywords: Cinema. Education. Vulnerability. Children's Protagonism.

\section{EL PROTAGONISMO INFANTIL A TRAVÉS DE LA RESISTENCIA EN KAMCHATKA (2003)}

\section{RESUMEN}

Nuestra presuposición es que el cine y sus dispositivos estéticos pueden revelar sutilezas que lo cotidiano tan inmediatista muchas veces no nos permite: la mirada del niño sobre el mundo y sus dramas inherentes 
a la infancia. ¿Y qué podemos acceder sobre las aflicciones infantiles ante el control social regido por la centralización del poder en los militares y por la pérdida de los derechos? La propuesta de este trabajo es emprender una discusión sobre la lectura del niño en un contexto social vulnerable a través de la película argentina Kamchatka (2003) y su potencia como ser de resistencia. Es bajo la óptica del protagonista de 10 años de edad, Matías (Harry), que acompañamos la confluencia de la tensión, de la ludicidad y también del enigma de la resistencia que los padres experimentan ante la dictadura. Este trabajo está vinculado a la búsqueda... tiene como metodología de investigación el análisis fílmico y toma como referencial teórico Adorno y Horkheimer (1985), Adorno (1992), Bernadet (1985), Bordwell (2013), Gardies (2006), Rojas (2014), Truffaut (2005). Los resultados apuntan al vigor del trabajo fílmico al revelar el impacto de la penetración imperativa de la barbarie de la dictadura en las diversas complejidades sociales, especialmente en la vida infantil.

Palabras clave: cine, educación, vulnerabilidad, protagonismo infantil

\section{INTRODUÇÃO}

\section{A criança protagonista no cinema e a estética de Kamchatka}

A arte cinematográfica constituída pelas imagens em movimento - a depender da qualidade de sua obra - impacta, toca e sensibiliza aquele que se propõe interagir com ela. O cinema permite viver um contexto reflexivo sob outra ótica, que é a perspectiva dos personagens. Acompanhar a narrativa a partir de outro referencial é ampliar nosso campo de visão e, consequentemente, outra compreensão pode emergir ao ocuparmos o papel de espectador, que lança sobre a vida um olhar a partir de lentes até então não experimentadas.

O acompanhamento e a vivência da narrativa fílmica, por meio do mergulho no enredo só é possível porque todo filme é uma construção de um conjunto de procedimentos estéticos que serão discutidos ao longo deste texto. É o manejo de uma série de opções arquitetadas pela equipe envolvida na obra sob regência do diretor que pode ou não transportar e fascinar o espectador. Nem tudo que é produzido torna-se acessível a quem assiste ao filme, por isso o retorno à obra é sempre um convite a descobrir aspectos anteriormente interditados, sempre um fragmento torna-se inédito, embora presente a priori. Os efeitos da leitura do composto audiovisual são da ordem da subjetividade do espectador, contudo a finalidade da obra é afetá-lo, é promover a imersão na narrativa e, ao mesmo tempo, a emergência de sensações e de reflexões.

Certamente alcançar o espectador é um objetivo que reverbera na produção cinematográfica. Considerar o espectador repercute no processo criativo do filme, pois implica no destaque e no trabalho em determinados aspectos da composição audiovisual "quer para the glorificarem os poderes de encantamento, quer para the criticarem os efeitos devastadores (ou ainda sublinharem a ambivalência desses efeitos)" (GARDIES, 2006, p. 221). Essa articulação entre audiovisual e espectador se dá, segundo ele, pela via do alto relevo, ora do baixo relevo. No cinema, a movimentação das imagens prevalece com o alto relevo. Em geral, a relação que o filme estabelece com quem assiste pode passar pela fascinação, pela identificação, pela aversão, pela pouca diferenciação entre o que é real e o imaginário, ou até mesmo pela eflorescência de sensações físicas e manifestações de emoções inexistentes antes do visionamento.

As trajetórias para a construção de sentido, a combinatória programada de diferentes temáticas e recursos estéticos (luz, sons, cores, ritmos etc), o desenlace da narrativa na recriação de circunstâncias vivenciais marcadas pela dramaticidade, repletas de emoções e de sentimentos "tendem a agir diretamente sobre os ritmos cardíacos, sobre a respiração e sobre o funcionamento do sistema nervoso de um espectador geralmente imobilizado onde está sentado" (GARDIES, 2006, p. 225).

Uma estratégia para essa afetação e captura do espectador é contar com a presença de criança(s), ainda mais quando ela (s) é (são) protagonista(s). Para Truffaut (2005, p. 35) é inerente à criança a poesia e capacidade de sensibilizar. Dependendo de qual é o seu lugar no enredo, ou ela pode atuar a favor da reiteração do imaginário social da candura ou do realismo, com seus júbilos e amarguras. $\mathrm{O}$ olhar da criança 
sobre o mundo se distingue do adulto pela dimensão espacial, pela intensidade das sensações, pelo temor do desamparo, pela literalidade da escuta, dentre tantas razões outras que não são mais acessíveis pelos adultos que recalcaram sua infância. Das questões e dos conflitos cotidianos aparentemente frívolos, "pode nascer um drama na tela, o que nos mostra que um filme de crianças pode ser elaborado em cima de pequenos fatos, pois na verdade nada é pequeno no que se refere à infância" (TRUFFAUT, 2005, p. 36).

Assim, a presença da criança é um fator que por si só aproxima o espectador, amplia a possibilidade de identificação e afeição. A graciosidade das crianças, a espontaneidade e capacidade imaginativa tendem a chamar a atenção e embrandecer quem adentra a narrativa ao assisti-la, pois por mais memórias recortadas, diluídas ou recriadas que temos da infância que tivemos, não é estranha a sensação de vulnerabilidade e de exposição a toda sorte que toda criança está suscetível. Mesmo diante do desamparo provocado pelo contexto tão adverso, ela é muitas vezes marcada pela insubordinação própria à infância, assim lança mão de subterfúgios e estratagemas lúdicos que subvertem o abandono, mesmo imersa no sofrimento, ela resiste a sucumbir apoiada na imaginação e nas figuras heroicas, como vemos em Kamchatka (2003). Ter a criança como protagonista impulsiona a atratividade, pois "quando vemos determinada criança fazer alguma coisa na tela, somos imediatamente jogados para trás, para nossa própria infância, ao mesmo tempo que parece que o que essa criança faz a infância inteira está fazendo" (TRUFFAUT, 2005 , p. 233). Há tempos que a criança no cinema ganha um espaço de notoriedade, o que pode ser elencado desde os filmes de Charles Chaplin, as diversas obras do neorrealismo italiano e diversas obras recentes em diferentes escolas cinematográficas, com destaque aos iranianos e também brasileiros das últimas décadas.

O visionamento do longa-metragem só é possível porque um conjunto de procedimentos estéticos se conjugam a favor da construção da narrativa ficcional. Atentar-se aos detalhes, a busca pela decomposição dos elementos técnicos do audiovisual e, consequentemente, a composição de uma discussão sobre as feições da obra fílmica é tarefa da análise fílmica. A leitura e a análise do texto fílmico têm como principal finalidade atribuir sentido aos significantes que, aos serem colocados em cadeia, estruturam a lógica narrativa. $O$ enredo, os personagens, os planos, os enquadramentos, a dramaticidade e a encenação, a sonoridade, a palheta de cores, são alguns dos elementos que se articulam na constituição da obra cinematográfica.

Cada um desses aspectos se coloca a favor da narrativa e pode favorecer a captura do espectador. Para a construção da atmosfera de Kamchatka (2003), a palheta de cores expressa as condições simbólicas que engendram as dinâmicas dos personagens. O clima de apreensão, de medo do desamparo, de cominação é sentenciado também nas cores predominantes ao longo do filme. A sobriedade das cores que perpassam pelos diversos tons de marrom e suas nuances, o verde escuro, o cinza e o azul predominam e climatizam a tensão e a angústia vivida pelo protagonista. $\mathrm{O}$ marrom que prevalece é resultante da combinatória do vermelho, do amarelo e do preto ou azul. Interessante é ver que os tons de castanho se contrastam em algumas cenas com o amarelo gema do carro da família - Imagem 1 - do vermelho sangue do casaco de Matías na fuga em busca do amigo. Nesses momentos destaca-se o personagem no ambiente austero de perseguição e violência que é a ditadura. As cores se alinhavam aos outros procedimentos estéticos que descortinam a ameaça direta do regime autoritário que é revelada claramente em uma cena logo após o início da narrativa.

De pronto, é evidenciado que o motor do texto fílmico será um longo flashback, uma estratégia narrativa de alteração temporal ao retratar no presente algo já vivido anteriormente por meio do resgate de lembranças. Esse retorno ao passado e da reconstrução de memória é anunciado por meio da voz em off do narrador, que emerge no início, em vários momentos do desenvolvimento e retorna no desfecho do filme. Embora não apareça a figura do personagem adulto, seu registro sonoro (sua voz de criança) compõe a cena e esclarece aspectos que enodam a história. O foco narrativo de Kamchatka (2003) está em primeira pessoa, em que o protagonista é o narrador-personagem, ou seja, autodiético.

O princípio do filme mostra Matias na escola brincando de "forca" (jogo de formação de palavras a partir de pistas e escrita letra a letra a partir da confirmação ou contrariedade da hipótese) com um amigo. Surpreendentemente sua mãe chega para buscá-lo na escola durante o decorrer da aula e a brincadeira é interrompida, 
porém o colega sai de sala para revelar a palavra em questão, "abracadabra".

Ao entrar no carro (vide Imagem 1) onde está o irmão mais novo também, Matías questiona a mãe, "para onde vamos?" Ao ouvir que a razão de sua saída da escola é ir a cada de alguns amigos, ele continua as indagações e faz solicitações acerca da aula de inglês e da possível ida à casa do amigo. Ao visualizar a barreira militar, a mãe demonstra muita apreensão e manuseia diversos documentos enquanto o carro ainda está em movimento. Ao ser orientada a seguir adiante pelo militar, as crianças observam uma cena em que uma pessoa é retirada de um carro e é violentamente abordada, retratada na Imagem 2. Essa é a primeira vez em que se mostra a família se livrando temporariamente da ameaça que assombra toda a narrativa, entretanto é a única vez que é evidenciada a atuação militar contra os civis.
Imagem 1

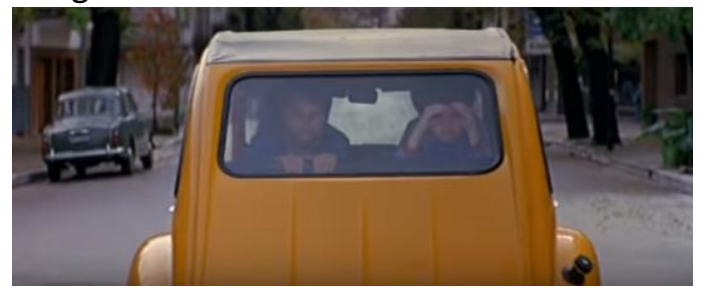

Fonte: Kamchatka (2003)

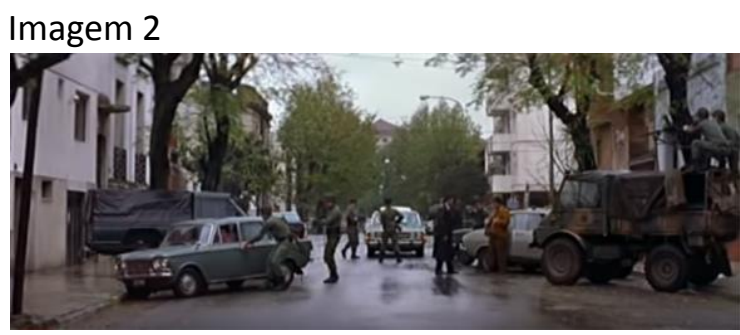

Fonte: Kamchatka (2003)
Passada a imensa aflição de não ser parada na barreira militar, a câmera objetiva mostra as crianças no banco detrás do carro muito atentas ao que escaparam. Logo, a câmera subjetiva imita o olhar das personagens infantis que testemunham as várias armas em riste direcionadas a um carro. Um homem é arrancado do veículo enquanto a câmera se distancia da cena de violência. Essa mudança da câmera é um dispositivo estético que nos permite visualizar o contexto em que se situam os personagens, como na câmera objetiva da Imagem 5 e também revela ao espectador a visão do protagonista com a câmera subjetiva da Imagem 6, como se tomássemos emprestado os olhos da criança e acessássemos seu interior distanciando-nos da violência empregada sobre os ocupantes do carro seguinte.

Essa primeira "escapada" da família dos ditames do poder militar é outro recurso estilístico chamado de flashforward, que se trata de uma pista lançada geralmente no início do texto fílmico e que ganha grande relevância no desenrolar da narrativa, adiantando um elemento do tempo futuro, porém muitas vezes não é reconhecido de pronto pelo espectador, $a$ posteriori compõe uma peça importante do quebra-cabeça parte do enredo. Esse dispositivo também esteve presente na palavra da brincadeira da forca mencionada no início do filme. Vejamos a seguir como isso comparece de forma mais insistente no enredo a partir do encontro da criança com o livro biográfico ilustrado do escapista Harry Houdini.

$\mathrm{Na}$ tentativa de amenizar o clima de medo, logo que chegam ao sítio mencionado anteriormente, os pais conversam com as crianças que agora eles exercerão papéis de personagens, adotando outros nomes e histórias, assim como as tais instruções para, caso seja preciso, se esconder e escapar do perigo. Assim, Matías ganha outro nome, Harry, sinal da admiração ao ilusionista.

A descoberta do livro para Harry é análoga ao encontro de um tesouro. O encantamento, a curiosidade e a idolatria do protagonista, mobilizados pela história, e os feitos do escapista Houdini são demonstrados novamente pelo dispositivo de alternância das câmeras objetiva e subjetiva. Esse mecanismo audiovisual é tão presente nessa obra que se torna um traço marcante do texto fílmico no intuito de convocar o espectador de se colocar na perspectiva da criança, como é possível verificar no recorte de diferentes momentos da narrativa, seja nas Imagens 1 e 2 , seja nos apresentados abaixo: 
Imagem 3

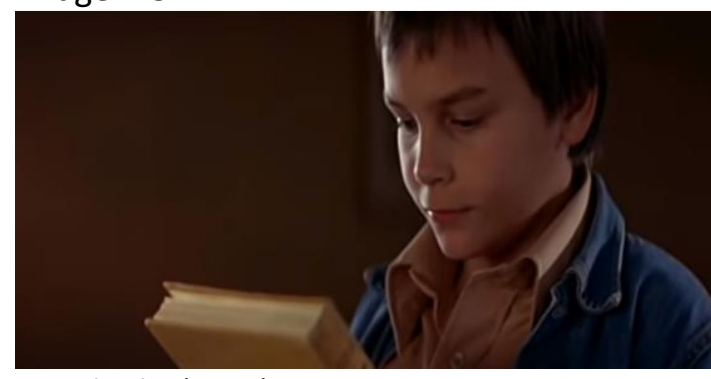

Kamchatka (2003)

Imagem 5

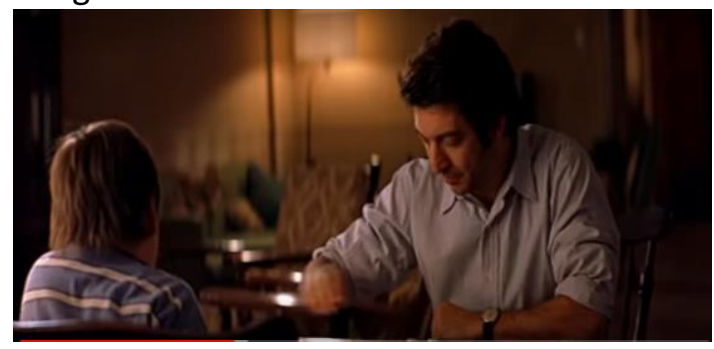

Kamchatka (2003)

Imagem 7

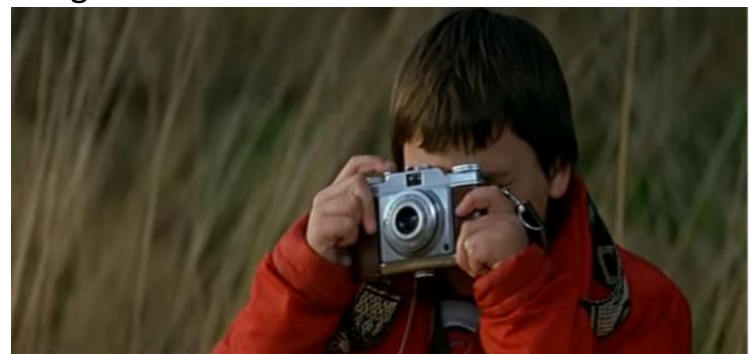

Kamchatka (2003)

Como já mencionado, a montagem envolve uma poética que imprime as permanências, as suspensões, os cortes, que asseguram uma dinâmica que provoca efeitos naquele que assiste à obra cinematográfica. Essa multiplicidade de planos, revezamento de câmeras e cortes, imprimem nuances que singularizam ainda mais a obra artística, o que também não é dissociado do contexto histórico de sua produção. Essa estética fílmica é definida por Bordwell como estilo, que é o "uso sistemático e significativo de técnicas de mídia cinema em um filme [...] é a textura das imagens e dos sons do filme, o resultado de escolhas feitas pelo cineasta em circunstâncias históricas específicas" (BORDWELL, 2013, p. 17).

Ao intercalar o foco no protagonista e sua ótica da realidade, vemos na Imagem 3 o momento emblemático de Harry ao se deparar com o livro Houdini e experimentamos na Imagem 4 o mergulho da criança na obra literária, em seu texto e ilustrações das ações prodigiosas do ilusionista,
Imagem 4

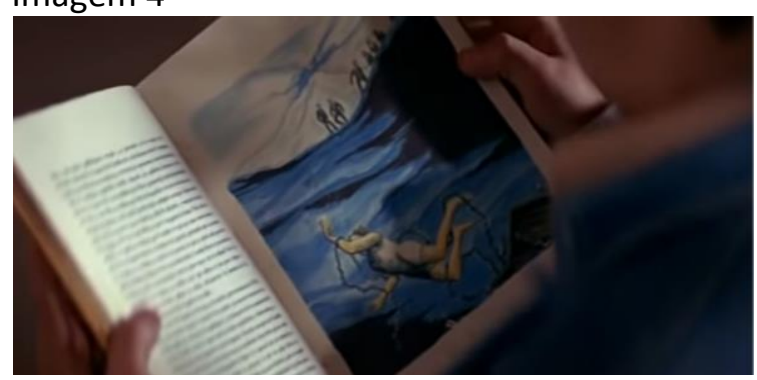

Kamchatka (2003)

Imagem 6

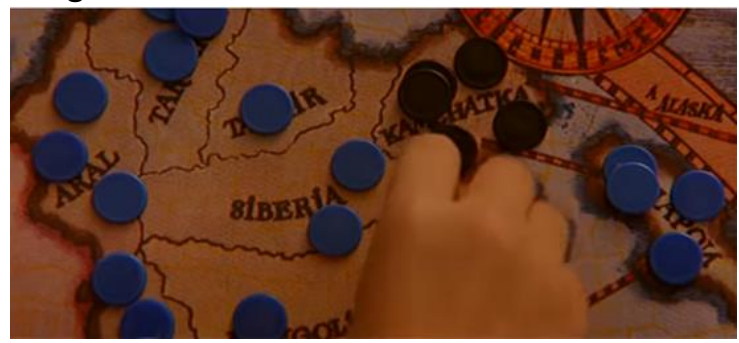

Kamchatka (2003)

Imagem 8

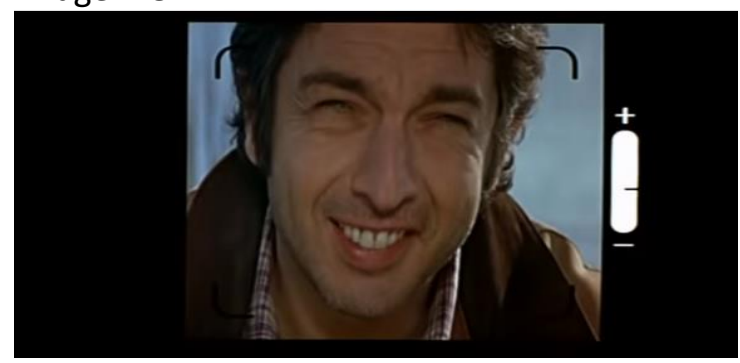

Kamchatka (2003)

como escapar de diversos obstáculos dentro da água. As Imagens seguintes revelam os frequentes e férteis diálogos entre Harry e seu pai. Nas Imagens 5 e 6, os personagens estão em um contexto de um jogo de tabuleiro, pautado na elaboração de estratégias e tomadas de territórios, assim a ênfase no protagonista se reitera e o cerne de seu olhar para os elementos do jogo. Nas Imagens 7 e 8 evidencia-se o uso da câmera fotográfica, como uma metalinguagem, a captura das imagens no interior do cinema, evidenciando o olhar da criança para aquela figura tão importante para sua vida. Esse dispositivo estético favorece a revelação do tempo da criança, o tempo do aqui e agora, da intensidade da vivência.

Retomando as Imagens 7 e 8, eles estão situados em uma cena em que a ótica da criança enquadrada na câmera fotográfica de forma que a contemplação do rosto do pai em close-up se dá em uma desaceleração do ritmo que conduz as expectativas do espectador, suas reações sensoriais e afetivas. A criança fita o pai, 
admirando-o sob a lente da câmera. Essa articulação de movimentos de planos e ângulos implica a produção de efeitos, como podemos ver no caso dos planos da Imagem 7 e o primeiríssimo plano da Imagem 8, em que esse revezamento dá a impressão de traduzir emoções recônditas dos personagens. Para o autor citado acima, esses aspectos dizem respeito às operações linguísticas em que constituem o texto cinematográfico, com o uso de uma gramática própria a cada diretor.

\section{O protagonismo infantil em Kamchatka (2003)}

No caso do filme Kamchatka (2003), dirigido por Marcelo Piñeyro, a vivência psíquica do espectador se conduz pelo protagonista, Matías, uma criança de 10 anos de idade situada no contexto da ditadura argentina dos anos 1970. O olhar da criança revela minúcias desse regime autoritário em que prevalece a austeridade e a supressão dos direitos humanos. As circunstâncias vividas por Matías são interpeladas sob o referencial da vivência doméstica impactada pelo contexto sócio histórico. O que é precioso dessa narrativa ficcional audiovisual é justamente mostrar o exercício do assombro de uma ameaça sentida, mas não percebida claramente pela criança e, ao mesmo tempo, a vivência de circunstâncias aparentemente ordinárias, que ganham, porém, uma carga árdua para o protagonista e seu irmão mais novo. A condução da criança engaja e emociona o espectador.

Nesse filme, a criança é duramente impactada nesse contexto ditatorial, em especial por sentir-se à deriva do não saber, do medo, das perguntas sem respostas, da percepção da angústia dos pais e que resvalam em si e das tentativas de acessar as informações, como pode ser percebido em alguns momentos em que a criança finge que está dormindo para ouvir a conversa dos pais ou tenta escutar atrás da porta o diálogo da mãe com uma amiga em um contexto de tensão e de preocupação. A força dramática das cenas ganha impulso pelo âmbito social. De forma delicada, o espectador sente o peso que a criança protagonista carrega na trama, até porque ele também experimenta, tal qual a criança, momentos de obscurantismo do texto fílmico, como um convite à elaboração ou a invenção de teorias do que a situação trata ou do que está por vir.

A ditadura argentina é um exemplar de outras que acometeram diferentes países da
América Latina no mesmo período. A título de trazer mais segurança aos cidadãos e livrá-los da suposta ameaça do comunismo, os militares ascendiam ao poder por meio de golpe de Estado chamado pelo eufemismo de revolução argentina. Para a manutenção do autoritarismo a modificação de leis a favor de si, a redução dos direitos civis e a criminalização das manifestações de oposição ao regime foram condições para sustentação da ditadura.

Kamtchaca (2003) faz parte de um espectro de produções latino-americanas que abordam formas de enfrentamento de regimes políticos que perseguem e reduzem as condições de vida de seus cidadãos. É mais um longametragem que aborda essas questões lançando luzes sobre os sujeitos mais sofridos e silenciados pelo poder governamental: as crianças. Cada qual com sua peculiaridade, a temática da infância implicada em um governo totalitário é abordada também no filme chileno Machuca (2004) de Andrés Wood, no argentino Infância Clandestina (2012) de Benjamin Ávila, no uruguaio Paisito (2008) de Ana Diés e no brasileiro O ano em que meus pais saíram de férias (2006) de Cao Hamburguer.

Esse conjunto de produções evidenciam as lutas, as resistências e os enfrentamentos de um período histórico que não cessa de ameaçar seu retorno e vigor que nos assombram nos tempos atuais. A presença das crianças serve menos ao entretenimento e mais à impressão de realidade. O foco sai da produção da busca do conforto para o espectador para o mergulho nas relações sócio-histórico-político-culturais a partir de uma apreciação diferenciada, que no cotidiano passa geralmente despercebida, à luz dos olhos da criança, em um jogo de revelação em meio ao ocultamento das técnicas cinematográficas em sua composição estética.

A história do cinema é em grande parte a luta constante para manter ocultos os aspectos artificiais do cinema e para sustentar a impressão de realidade. O cinema, como toda área cultural, é um campo de luta, e a história do cinema é também o esforço constante para denunciar este ocultamento e fazer aparecer quem fala (BERNADET, 1985, p. 20). 
Esse cenário de hostilidade é revelado no prelúdio do filme por meio da legenda que traz o marco temporal "outono de 1976", poucos dias depois do Golpe. Nesse ínterim milhares de argentinos foram perseguidos, sequestrados, torturados e mortos. $\mathrm{O}$ amedrontamento tornouse um imperativo para a população e, na narrativa em questão, é perceptível que os pais de Matías estavam envolvidos em um movimento de oposição e de resistência, por isso o temor se presentifica no desenvolvimento de toda a trama.

Nem de perto sentimos o baque dos acontecimentos reais e tenebrosos de uma Ditatura Militar que durou de 1976 a 1983, com uma rede de terror arquitetada para aniquilar a luta política e social das classes trabalhadoras, rumo à consolidação do neoliberalismo e que, segundo Rojas (2014, p. 168), "cumpre seu objetivo de recompor a ordem", mas na ambiência do filme, especialmente entendendo que o período estava apenas em seu início, em passagens em que sugere-se abertamente a prisão e morte de amigos e conhecidos dos pais de Matías, sente-se a força militar que começa a fechar estradas e possibilidades de fuga daqueles que eram ativistas, combativos de organizações de esquerda, ou seja, a resistência que sofreu repressão. Na leitura de Rojas (2014) com relação à sociedade civil, há a negação de uma luta de classes, e nós partimos do engendramento desse contexto para a análise fílmica, ou seja, há uma questão política:

[...] que entende que a sociedade está dividida em classes, e que as frações das classes dominantes na Argentina, no bloco no poder, defenderam e justificaram o terrorismo de estado. A ditadura militar, nesses termos, triunfou, cumpriu seus objetivos essenciais, eliminou o que denominava a "subversão marxista" e, com isto, qualquer possibilidade de mudança social no imaginário da cidadania no curto prazo, e realizou as mencionadas

transformações

econômicas neoliberais de largo alcance (ROJAS, 2014, p. 171).
Para Adorno e Horkheimer (1985), o aspecto da ordem, que justifica as perseguições, "não pode viver sem a desfiguração dos homens" e não o contrário, tendo em sua essência a violência que se emprega em prol do que se quer chamar de harmonia, hegemonia, unidade, universalidade, palavras que ganham força na estratégia dita democrática que força a adaptação do diferente, do dissidente, do rebelde, do que resiste à dominação.

A integração à coletividade bárbara encontra caminhos nesse discurso em nome da ordem e o movimento dos militares combina a sua defesa à da família, da pátria, cria-se um clima de defesa dos "bons costumes", do "bem comum", com todo o aparato econômico comandando ações diversas de limpeza social. $\mathrm{Na}$ película uma cena em especial evidencia todo esse contexto político: Baixinho (irmão caçula), Matías e o pai interagem na sala com a televisão ligada, o pai conserta um relógio enquanto as notícias anunciam que $o$ ministro negava claramente que o executivo tivesse em seu poder ou que estivesse preso algum dos militantes da lista; afirmava inclusive que estava sendo escrito um novo capítulo na história econômica argentina, uma nova situação política de abertura do mercado para as empresas estrangeiras, com "liberdade para as forças produtivas". O comentário irônico do pai nos indica claramente o posicionamento do diretor, a verdade por detrás dos fatos armados: o que produzem as forças produtivas? Mais miséria.

A abordagem de um período histórico tão hostil a partir do ponto de vista da criança é um artifício exitoso na construção de uma narrativa em que o quadro conjuntural de repressão militar é revelado de forma distinta de um longametragem histórico. A criança ali ameniza e amortece os impactos da realidade tratada, já que o foco se distancia dos fatos históricos e dos eventos políticos. O lugar da criança é o da captura de pistas de que algo não vai bem e especialmente a vivência da tensão, do medo da perda dos pais e as incógnitas dos movimentos das figuras parentais.

\section{Símbolos da resistência capturados pela sensibilidade da criança}

Baixinho e Matías de fato acompanham o pai na cena descrita anteriormente, mas tratam logo de brincar, o irmão mais velho pede para ser amarrado na cadeira pelo caçula, que mesmo usando a expressão de "branquear" (silenciar) os 
prisioneiros, não parece compreender (e não compreende) seu real sentido.

Um dos trunfos mais importantes da obra talvez seja o uso de diferentes símbolos com os quais o diretor sinaliza a possibilidade de resistência contra a situação de vulnerabilidade em que se encontra a família. Tudo permeado pelo jogo, pela imaginação, pelo afeto, elementos normalmente atribuídos à infância, contrabalanceados pela premente violência que assola o país, a qual também embala os acontecimentos porque passam Matías, seu irmão e seus pais, núcleo humano central da narrativa.

Adorno e Horkheimer (1985, p. 149) mencionam a expressão "constelação do terror" que dialoga bastante com todo esse mecanismo de apagamento da chama mimética que habita os comportamentos daqueles que se voltam contra o rigor do progresso técnico, econômico e político no processo civilizatório, entre eles os ciganos, os atores. As crianças também, segundo eles, são vítimas desse mecanismo que busca a práxis racional, a reflexão controlada, sua resistência compõe ações próximas da diversão, totalmente contrárias à condição de uma "pedagogia que desacostuma as crianças de serem infantis". Kamchatka (2003) resgata essa possibilidade do viver a infância como forma de resistência numa situação adversa de perseguição, o núcleo familiar apresentado transborda o que na civilização da ordem e da reificação das relações humanas é reprimido: o toque, o aconchego. Adorno e Horkheimer (1985, p. 150) analisam, inclusive, como o comportamento infantil é rico na sobrevivência do gesto imitativo, "a mímica indisciplinada é o ferrete da antiga dominação", a mimese aparece então como substância viva cultivada no autêntico gesto infantil por si só insurgente e rebelde.

Situações como as de guerra, de perseguição numa ditatura, retraduzem a essência da vida no quinhão da violência guardada a quem antagoniza aqueles que agem guiados pela cegueira da irmandade inflamada pela prescrição das normas. À luz da discussão de Adorno e Horkheimer (1985, p. 151), esmiuçando "os limites do terror sem limites" de perseguição aos judeus, na esteira do anti-semitismo, e que nos serve muito bem como referência para a análise, vemos desenhada a potência da indiferença para com o outro que ameaça desorganizar a obra dos homens de ação, dos políticos, militares, chefes dos campos de concentração, demagogos, fascistas.

Todos os outros são "muito espaçosos" e devem ser recolocados em seus limites, que são os limites do terror sem limites. Quem busca refúgio não deve encontrá-lo; os que exprimem aquilo a que todos aspiram, a paz, a pátria, a liberdade, ou seja, os nômades e os saltimbancos, viram sempre recusado o seu direito de cidadania (ADORNO; HORKHEIMER, 1985, p. 151).

Assim se reabilita o horror que outrora a chamada civilização proíbe, em nome do interesse pretensamente racional permite-se para além da perseguição, supera-se a tortura, mata-se, elimina-se, emprega-se sentido às fórmulas fascistas, à disciplina ritual, aos uniformes, reanima-se todo um aparato e um mecanismo de combate aos revolucionários, rufam-se tambores em prol de uma defesa legítima diante da terrível ameaça que paira no ar e, nas palavras dos autores, liquida-se a consciência moral:

[...] de qualquer modo a
consciência moral está
liquidada no fascismo,
onde a responsabilidade
pela mulher e pela criança,
tão penosamente
cultivada pela civilização
burguesa, de novo
desaparece por trás da
necessidade em que se
encontra o indivíduo de se
orientar constantemente
pelo regulamento a ele
imposto (ADORNO;
HORKHEIMER, 1985, p.
163).

O olhar de nosso protagonista também evidencia a sensibilidade em meio ao caos instalado de uma ditadura, Matías, em três momentos diferentes do filme, avista três figuras da natureza com as quais tem contato, descontruindo ou significando a realidade dura de enfrentamento da tensão - lagarta, sapo, pomba. No texto fílmico de Kamchatka, esses animais são signos que se colocam na cadeia textual que vão dando ao espectador o entendimento de como Matías vai elaborando cada episódio que envolve desde o ter que abandonar sua casa, amigos e escola para um novo começo, saber que é preciso aprender a sobreviver sozinho, à finalmente, tentar cuidar das feridas que enredam concretamente o corpo 
e que podem ser fatais. Um lento e doloroso processo de entendimento acerca das mudanças em sua vida vai se instalando e finalmente $o$ vemos enfrentando a morte de um símbolo de paz e liberdade, cena que conta com a participação de seu pai (não por acaso) com feridas nas mãos quando tenta salvar o pássaro.

A lagarta é encontrada logo que chegam ao sítio que serve de refúgio à família, o pai instrui as crianças sobre o sinal de alerta e o que devem fazer se o ouvirem: mergulhar por entre as plantas de uma cerca natural e atravessar em direção ao carro para uma possível fuga. Tudo é encenado como numa brincadeira de mímica. A lagarta está em uma das folhas, só Matías a vê, parando por um segundo. O olhar infantil capaz dessas delicadezas pode transfigurar a realidade dura para além do jogo, traduzindo para o comportamento a leveza de uma compreensão que há muito perdemos na seriedade das palavras e ações. Isso, no entanto, não se produz sem sofrimento. Faz lembrar o belíssimo aforismo 114 de as Mínima Moralia de Adorno, Heliótropo. Já no título percebemos a referência a uma flor perfumada, e no texto encontramos uma criança que sente o perfume da visitante fria e dedicada a suas tagarelices do dia a dia como um convite a penetrar no mundo adulto a que ela ainda não tem acesso, mas crê recheado de aventuras. convidada deixa na cómoda, enquanto lhe é permitido olhar na abertura da sua bagagem tem, ao respirá-lo pela primeira vez, um aroma que é uma evocação. As malas com insígnias da Suvre-tathaus e da Madonna di Campiglio são cofres em que as pedras preciosas de Aladino e AliBábá, envolvidas em ricos panos, e os quimonos da visitante, trazidos em vagões de liteiras das caravanas da Suíça e do sul do Tirol, ficam à mercê da insaciável curiosidade. E assim como nos contos as fadas falam aos meninos, assim fala a convidada, séria e sem afectuosidade, à criança da casa. Esta, logicamente, pergunta pelos países e pelos povos, e a dama, que não está familiarizada com ela e vê nos seus olhos simples fascínio, responde-lhe com observações fatalistas sobre o enfraquecimento cerebral do cunhado ou os assuntos matrimoniais do sobrinho (ADORNO, 1992, p. 168).

A visita sem tato e, no entanto, viajada, desperta a possibilidade de diferentes roteiros, conhecer novos mundos, a quinta-feira sem graça, quando nada de especial acontece, vira dia de festa, capaz de acelerar corações como em feriados, como o natal. O autor usa de palavras como amor e felicidade neste dia de recepção de uma hóspede que nem ao menos se esforça para agradar, mas o olhar da infância, embalado pela magia e esperança, vê nessa brecha da rotina uma promessa de prazer. Depreende-se da passagem a ironia do autor, articulando dialeticamente dois mundos que seriam intransponíveis, mas que ganham beleza a partir da interpretação brincante da criança. A indiferença dos adultos não é capaz de esvanecer o sentimento infantil que resiste no pacto para com outra versão dos fatos.

Já o sapo aparece em três momentos, relacionado à piscina e à amizade que Matías acaba desenvolvendo com Lucas, um rapaz que se refugia por alguns dias com a família no sítio, aparentemente um estudante. Na primeira cena, evidencia-se sua descoberta, Matías e Baixinho o veem pulando na piscina, território proibido para os garotos. Quando aparece novamente, desenvolve-se a tentativa de recolhimento de seu cadáver pelos garotos, que o encontram boiando, ele todavia sai pulando. Matías cria uma espécie de prancha com uma tábua, dizendo ao irmão que o mecanismo se destina a ensinar ao sapo que "aprenda a sobreviver sozinho". Finalmente, a última cena é o enterro do sapo, ela coincide com a partida de Lucas, o episódio é encarado com muita tristeza, Harry (como se apresenta para Lucas, cujo nome também é outro e não chegamos a sabê-lo) tenta ali mostrar-se indiferente, sofre duramente a perda, tanto que não consegue se despedir de fato apesar da tentativa de Lucas que lhe deixa uma camiseta de lembrança. A inflexível realidade vai se empoderando, Harry perde um amigo, mais um, 
é obrigado a enterrar mais uma parte de suas emoções que convulsionam pelo grito de decepção e abandono.

O encontro com a pomba dá-se um pouco antes do episódio com Lucas, na ocasião em que fazem uma visita ao avô por ser seu aniversário, mas associa-se mais ao final da história, na relação sublinhada com o pai, é quase uma sugestão do que aconteceria, visto que a pomba é encontrada se debatendo em arame farpado e seu pai, na tentativa de salvá-la, acaba por ferir-se nas mãos. A compreensão do evento poderia passar despercebida, não fosse 0 conteúdo tão relevante apresentado pelo animal escolhido, a sensação que fica é a de impotência, não houve como resgatá-la sem graves consequências: a ameaça de morte da liberdade é muito palpável aqui, mas a mensagem queda incólume, tentar salvar-se é preciso.

\section{A teia de personagens}

Kamchatka (2003) é um filme que segue a cadência da vivência de uma família constituída por pai, mãe e dois filhos. Ao fugirem das forças militares para uma chácara, a convivência doméstica é marcada pelas trocas afetivas entre eles, atravessadas pelo amedrontamento. A cadência das cenas segue a dinâmica da criança protagonista, decorre daí a centralidade nos personagens, no núcleo familiar e outras figuras afetivas que agregam mais elementos da narrativa. Cada um deles é uma expressão dos laços que abrem novos acontecimentos e movimentos do enredo.

Os diálogos de Matías com a mãe são repletos de carinho e de cuidado, mas também permeados pela tensão e pela apreensão que ela tenta amenizar. Frequentemente, a relação olhos nos olhos estabelecida entre eles é marcada pela acolhida, pela escuta atenta e sensível da mãe das questões e das queixas da criança, tal qual apresentado na Imagem 9.

O pai é uma figura também muito presente, dedica sua atenção aos filhos e compartilha com eles atividades e diálogos em um teor lúdico e orientador, como a Imagem 10 mostra. As crianças são efeitos desse amor, em casa têm espaço para as manifestações de suas insatisfações e de seus temores. A fuga e o isolacionismo da família afastam as crianças da escola e de sua rede familiar. Não sem resistência, a visita à casa dos avós foi um alento.

\section{Imagem 9}

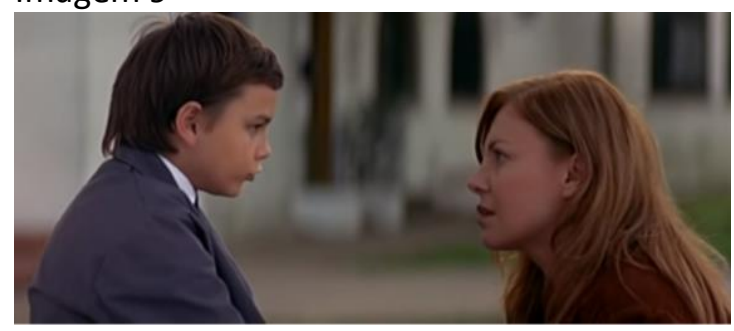

Fonte: Kamchatka (2003)
Imagem 10

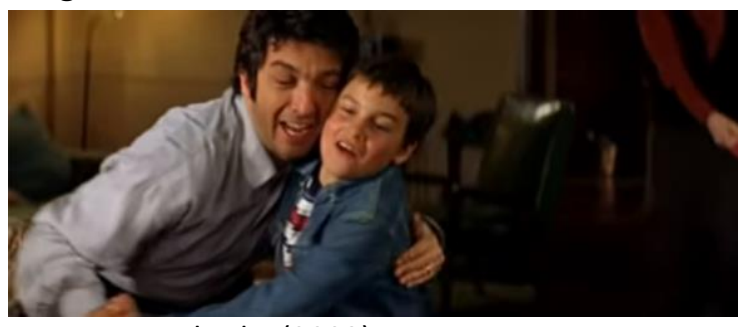

Fonte: Kamchatka (2003)
O avô é sujeito da escuta, como o posicionamento corporal dos personagens da Imagem 11 evidencia, que passa um longo tempo acessando o relato de Matías e toda a mudança recente em sua vida. A avó é outro oásis de quem estava recluso e exilado sem o domínio dessa realidade, porém incomodado com as consequências dela. É no quarto que foi do pai, chamado pela avó afetuosamente de "máquina do tempo", que eles dialogam de maneira terna, exposto na Imagem 12. A convivência com os avós apresenta as memórias da família, recapitula as experiências e reconfigura novas histórias.

A acolhida dos avós é um bálsamo para as crianças, porém para os pais torna-se a última alternativa na luta pela sobrevivência. Nesse contexto em que paira a preocupação e a aflição, uma trégua vivida foi a noite de observação do céu estrelado no quintal dos avós, em que toda família se reúne para contemplar o céu e encontrar estrelas cadentes. Há um movimento fugaz, de desaparecimento, que se aproxima, resta aproveitar esse instante. 
Imagem 11

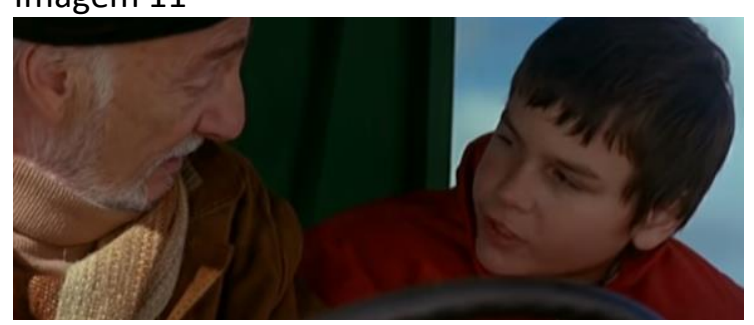

Fonte: Kamchatka (2003)

Outro personagem que ganha um espaço significativo no enredo é Lucas (já mencionado), um jovem que ganha guarita na família, pois certamente é alinhado aos movimentos de resistência ao regime governamental. Inicialmente Matías o questiona "o que você faz aqui?" Lucas responde que está em uma missão secreta. Em momentos de ausência dos pais, é o jovem que cuida das crianças e torna-se um valioso interlocutor. Embora sua presença amiga dê vitalidade ao cotidiano, ele pouco revela sobre detalhes $e$ as suas circunstâncias para o protagonista. Com frequência é interpelado pela criança, é com ele que Matías compartilha suas brincadeiras de escapismo, inspira-se nas atividades físicas de Lucas, o último torna-se um referencial para dirigir suas questões.

O estudante, desde o primeiro encontro com Harry (Matías) tenta conquistá-lo, oferecendo-se para preparar um chocolate batido, empreendendo uma conversa sobre mágica, assim que tem contato com o livro que Harry carrega de Houdini, nessas ocasiões Harry mostra-se bastante reticente. É como se não quisesse se entregar a uma relação que inconscientemente sabe que lhe trará dissabor. Mas, de maneira inteligente, Lucas percebe que Harry quer manter a forma física perfeita como o escapista que admira, a referência à resistência aparece quando o rapaz explica à criança como deve correr e que "é uma questão de resistência, nunca ganha o mais rápido, ganha quem aguenta"; um diálogo acerca dos aprendizados na vida, bastante filosófico, se segue:

L: -Tudo o que é bom a gente tem que aprender.

$\mathrm{H}$ : -Tem coisas que a gente sabe desde que nasce.

L: -Mas tem que aprender a fazer direito.

$\mathrm{H}$ :-De verdade?

L: -Pensar, por exemplo. Essa é uma.

Juntos, já em sintonia, com o verdadeiro

aceite da amizade se concretizando, vão repetindo verbalmente ações que são aprendidas
Imagem 12

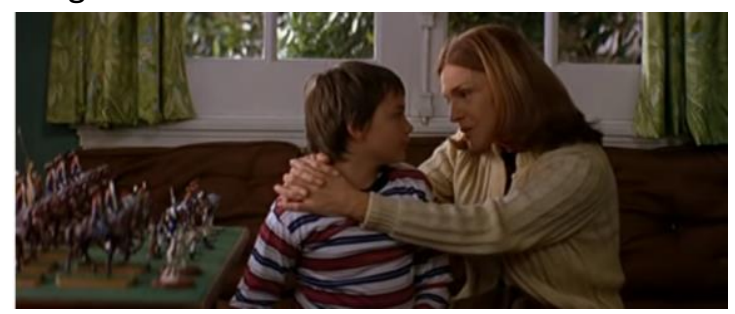

Fonte: Kamchatka (2003)

ou devem se aperfeiçoar ao longo da vida: nadar, respirar, mover-se, caminhar, correr, sentir, falar, rir, olhar, tocar, brincar, cantar. Os verbos se enumeram na corrida conjunta, a mensagem do diretor por detrás da cena é perspicaz. Na infância é possível relacionar-se com entes promovedores da uma formação humana, capazes de nos fazerem entrar em contato com um saber que combina a razão e a emoção, é preciso aprender do mais básico movimento físico ao mais refinado sentimento, a junção dos dois lados, que não deveriam nunca se separar, é o que nos faz humanos e nos impelem ao horizonte de esperança e de resistência quando o mundo nos impõe as mordaças.

Em certo momento, Lucas é indagado "você não tem amigos? Nunca os vê? Nem liga para eles? E se não voltarem... papai e mamãe?" A partida de Lucas significa uma ida sem volta, ele sabe disso, entende a gravidade nas pistas que o rapaz lhe deixa por responder enfaticamente com a mesma frase várias de suas perguntas: "pergunta incorreta"!

Cada personagem é um fio que amplia a rede de relações de Matías, órgãos da anatomia do filme que compõem o enredo permeado pelos vínculos entre eles, vínculos marcados pela afetividade, pela disponibilidade ao diálogo e ao cuidado. Cada qual encara os desafios apoiandose na busca da união, entretanto, a dissolução dessa segurança não é só uma ameaça, é uma possibilidade que comparece como um assombro.

Duas linhas de ação no roteiro de Kamtchatka (2003): a presença do escapismo e o jogo de guerra

O que se destaca nas Imagens 3, 4, 5 e 6 são dois signos fundamentais na construção desse texto fílmico: o livro que retrata as façanhas de Houdini e o jogo de tabuleiro. Eles merecem realce aqui, pois exercem um papel simbólico significativo no roteiro ao dar o tom de presentificação de componentes próprios a essa 
narrativa e também de pistas crescentes para o desenrolar da narrativa. Seus aspectos subliminares ganham cada vez mais corpo e superfície ao longo da obra.

Harry Houdini (1874-1926), codinome do húngaro Ehrich Weisz, viveu a maior parte de sua vida nos Estados Unidos e tornou-se mundialmente reconhecido por propagar uma vertente do ilusionismo intitulada escapologia. Colocava-se em situações difíceis de aprisionamento, seja algemado embaixo d'água, amarrado dentro de caixas, dentre outras circunstâncias que exigiam muito esforço físico e habilidade. Seus truques exerciam grande fascínio e admiração, e sua história inspirou e se desdobrou em livros, revistas, filmes, capas de álbuns e séries de televisão.

Sua biografia torna-se importante no contexto da narrativa de Kamchatka (2003), pois logo que o protagonista encontra o livro, dedicase à leitura, toma Harry como seu nome, brinca de escapar de cordas e de amarrações, é instruído pelo pai a seguir alguns procedimentos caso esteja em perigo... Aliás, a cena preambular do filme é uma brincadeira que incentiva a descoberta da palavra "abracadabra", que remete ao ilusionismo. Logo sua mãe consegue esquivar da blitz militar e, assim, os acontecimentos se encadeiam nessa trama que resultam na fuga final dos pais. Portanto, as evasões e os escapes do regime ditatorial comparecem de diferentes formas ao longo do filme e a criança dá o tom de ludicidade ao se fascinar e brincar com a história do grande mágico.

\section{RESULTADOS E DISCUSSÃO}

Harry enfatiza em suas falas, a partir da leitura da vida e façanhas de Houdini que ele não é um mágico e sim um escapista, cujas características enumeram fatores como "disciplina, concentração e coragem". A escolha das palavras aqui é extremamente importante, uma vez que as circunstâncias extremas vão se encadeando e enredando a personagem, que, no auge da aflição vivenciada, ensaia uma fuga à procura do amigo Bertuccio, o mesmo da brincadeira da forca do início da história.

Planejar suas ações, combinar o silêncio proposital do irmão, pegar o trem rumo à cidade, tudo é feito sem amadorismo, mas é emblemático como em sua narração Harry diz que na leitura da vida de Houdini tudo se explicita, os fatores que diferenciam um escapista de um amador, detalhes de seus feitos, mas nada sobre como ele fazia para escapar, nada prepara o garoto para o desfecho de sua escapada: a mãe do amigo mente muito gentilmente sobre sua presença em casa, Harry sabe que ele se encontra por tê-lo visto entrar, mas ela cria impedimento para o encontro. A decepção do protagonista vai nos preparando para o clima soturno, a cena em que a mãe de Bertuccio fecha a porta ao menino ao se despedir dele com a mentira é coroada pelo escurecimento dos corredores. A doçura nas palavras da mulher é traída pelos gestos de desconfiança e vigia, é como ninar crianças falando da desgraça alheia, como nos adverte Adorno em seu aforismo 128, "Regressões".

Quão para trás da delicadeza de tais cortinas ficam as flores. Nada nos aparece como a mais perfeita claridade do que a obscuridade inconsciente, nada substitui o que alguma vez poderíamos ser excepto o sonho de jamais termos nascido. "Dorme em paz, / fecha os olhinhos / ouve a chuva a cair, / escuta o cãozinho do vizinho a ladrar. / o cãozinho mordeu no homem, / rasgou as roupas do mendigo, / o mendigo corre para o portão. / Dorme em paz." A primeira estrofe da canção de embalar de Taubert causa arrepio. Todavia, os seus dois últimos versos bendizem o sono com a promessa da paz. Esta não se deve inteiramente à dureza do burguês, à tranquilidade de ter afastado o intruso. A criança, cansada e serena, já quase esqueceu a expulsão do estranho que, no Liederbuch de Schott surge como um judeu - e no verso "o mendigo corre para o portão" pressente o descanso, sem pensar na miséria dos outros (ADORNO, 1992, p. 191) 
A visão do adulto é capaz dessas distorções em nome da manutenção das aparências que ele deseja, como se, nas palavras do autor, no suave sono da criança pudesse esquecer-se da mesma maneira a violência. A razão da mãe do amigo de Matías é ocultar, a quem quer que fosse, vestígios de relações ainda existentes para com sua família, não importando ali os sentimentos da criança, a perda do afeto puro e sincero de uma amizade que nada tem a ver com os acontecimentos ao derredor. Como se nina uma criança descrevendo o menoscabo para com outro ser humano? Como se mente descaradamente e seriamente diante do aberto sorriso infantil que declara saudades e pede permissão para voltar, mesmo recebendo a inverdade tão abertamente?

Em um mundo guiado pelo contrassenso, as regressões se tornam regras e a ordem flutua, com desprezo à dor e ao infortúnio alheio: o que importa para a senhora distinta pelo que passam Matías e sua família? Fechando a porta ao menino, ela resguarda a si e aos seus de quem se atreve a questionar o regime. $\mathrm{E}$ ao retornar para a casa, a criança se queixa que o livro de Houdini não conta como ele escapa.

O jogo de tabuleiro é outro elemento muito significativo na ação dramática que ocupa um lugar inicialmente de captura do espectador pelo mistério: TEG (Tática e Estratégia de Guerra), conhecido como WAR, jogo competitivo de conquistas de territórios, acaba sendo a grande metáfora para a vida e acontecimentos de nosso pequeno protagonista. É uma brincadeira rotineira entre pai e filho, na qual este último sempre perde. Numa partida histórica, na verdade a última entre os dois, Harry parece avançar para a vitória, ganhando países e deixando seu pai isolado em Kamchatka. Num verdadeiro exercício inconsciente da vida justa, para usar uma expressão de Adorno (1992, p. 221), do aforismo 146, Mercearia, o jogo projeta a possibilidade do que na vida poderia acontecer: a resistência, ganhar espaço e transformar a realidade de perda, isolamento, vida clandestina, dominação do poderio militar. David Vicente (nome assumido pelo pai em referência a uma personagem da série que assistem, Os Invasores) vira o jogo e passa a derrotar Harry, reconquistando, a partir de um único país, Kamchatka, muitos outros, e angariando outros.

$\mathrm{Na}$ infância, o autor supracitado nos adverte para a beleza e riqueza da percepção das crianças, percepção que ele chama de espontânea, ainda não contaminada pela resignação, pelo embotamento. David quer manter essa essência em Matías, ele poderia perder propositadamente, ou mesmo desistir quando em situação difícil na partida. Como em muitos outros momentos do filme, este é de honestidade, vivenciado ativamente pelos dois, uma verdadeira experiência, urdida no "valor de uso, contra o valor de troca". Tais aspectos podem ser corroborados com a finalização deste tópico a partir das contribuições de Adorno.

Mas as crianças não estão, como opina Hebbel, tão enredadas nas ilusões da "estimulante variedade" para que a sua percepção espontânea não apreenda a contradição entre o fenómeno e a sua fungibilidade, que a percepção resignada dos adultos já não consegue registrar, nem tente a ela subtrair-se. $O$ jogo é a sua defesa. À criança não corrompida causa estranheza a "peculiaridade da forma equivalente": "O valor de uso torna-se a forma fenoménica do seu contrário, do valor" (Marx, Kapital I, Viena, 1932, p. $61)$. Na sua actividade sem finalidade toma partido, mediante uma artimanha, pelo valor de uso contra o valor de troca. Ao despojar as coisas com que se entretém da sua utilidade mediata, procura resgatar, graças ao seu trato com elas, aquilo que as torna boas para os homens, e não para a relação de troca, que deforma igualmente homens e coisas. O carrinho não vai a nenhum lado, e os pequenos pipos que transporta estão vazios; mas são fiéis à sua determinação enquanto não a põem em prática, enquanto não participam no processo de abstracção que nivela aquela determinação com tal 
abstracção, mas permanecem suspensos quais alegorias daquilo para que especificamente existem (ADORNO, 1992, p. 221).

\section{CONCLUSÕES}

No mundo infantil ainda reina o prazer do fazer, sem formas equivalentes que emudeçam a intuição ou rotulem a direção da ação que tem como parâmetro um valor intercambiável e uma utilidade. David e sua esposa buscam no calor dos acontecimentos, preservar a alegria, a ludicidade, deixar marcas poéticas, amorosas e saudáveis nos filhos, seja nos chistes constantes à mesa na hora das refeições, nas demonstrações abertas de carinho entre os dois e para com os filhos, nas falas e danças, na contemplação do céu, pequenos lembretes de sensibilidade que protegem as emoções para que não se esvaiam em meio ao sofrimento.

0 relato/narrativa de Matías (Harry) poderia transbordar amargura, mas não é isso que ele celebra, a mensagem de resistência é forte, acalentando nossas sensibilidades e chamando à luta, à consciência de que não há vida justa sem humor, amor, humanidade para todos, condições de igualdade e de voz, de liberdade. Os pais de Matías e Baixinho precisam fazer parte de um movimento que defenda isso para que as palavras acima não sejam apenas signos, mas concretude na vida futura dos dois. Kamchatka é a palavra que o pai sussurra no início do filme para Matías, cena retomada no final em que ele, como narrador diz "Na última vez que o vi, meu pai me falou de Kamchatka. Dessa vez eu entendi. E cada vez que joguei meu pai estava comigo. Quando o jogo ficava difícil eu fazia como ele e sobrevivi. Porque Kamchatka é um lugar onde a gente pode resistir".

\section{Apesar dos pesares}

A sincronia entre os movimentos das imagens e dos sons, a articulação entre corpo e voz, são enriquecidas não só com as alternâncias entre ruídos ambientais, vozes, silêncio, todo aparato sonoplasta, mas também com a presença das canções na trilha sonora. Em Kamchatka (2003) a presença musical é arquitetada por músicas instrumentais, Calhambeque, de Erasmo Carlos, interpretada por Caetano Veloso, The way you look tonight, Son tus perjúmenes mujer. Contudo, digna de nota é a música de fechamento do texto fílmico em que Matías visualiza a fuga dos pais. O carro cada vez mais distante deixa espaço maior para o texto poético musicado "Palavras para Julia" (1995), interpretada por Liliana Herrero. A canção fala sobre o imperativo das contradições da vida, que embora bela, repleta de sofrimentos, nos convoca à luta.

Embora ficcional, o texto fílmico é um intertexto que aglutina diferentes modalidades artísticas, uma inter-relação que funciona com a coordenação de elos que interfere inclusive na organização temporal da narrativa. A música supracitada está a favor da revelação de que o filme é um grande flashback, que se configura como um recuo no tempo, das memórias do protagonista. Ela está a favor da narrativa, do envolvimento do espectador e da alteridade ao engajar a possibilidade de colocar-se no lugar do outro, uma vez que a música "pode influenciar uma personagem, influir uma personagem, evoluir em função da acção, ser emitida de uma fonte no ecrã... e, por isso, fazer parte da diegese" (GARDIES, 2006, p. 63).

Tu no puedes volver atrás
porque la vida ya te
empuja como un aullido
interminable
interminable.
Te sentirás acorralada
te sentirás perdida o sola
tal vez querrás no haber
nacido
no haber nacido.
Pero tú siempre acuérdate
de lo que un día yo escribí
pensando en ti como
ahora pienso.
La vida es bella ya verás
como a pesar de los
pesares
tendrás amigos tendrás
amor
tendrás amigos
Un hombre solo una
mujer
así tomados de uno en
uno
son como polvo no son
nada
no son nada.
Entonces
acuérdate
de lo que un día yo escribí
pensando en ti como
ahora pienso.

Tu no puedes volver atrás empuja como un aullido interminable interminable. Te sentirás acorralada te sentirás perdida o sola nacido no haber nacido.

Pero tú siempre acuérdate de lo que un día yo escrib pensando en ti como hora pienso.

la ya verás

pesares

tendrás amigos tendrás amo

tendrás amigos

mujer

uno

nada

ahora pienso. 
Nunca te entregues ni te apartes

junto al camino nunca digas

no puedo más y aquí me quedo

y aquí me quedo.

Otros esperan que resistas,

que les ayude tu alegría, que les ayude tu canción entre sus canciones.

Entonces siempre

acuérdate

de lo que un día yo escribí

pensando en ti como ahora pienso.

La vida es bella ya verás como a pesar de los pesares

tendrás amigos tendrás amor

tendrás amigos.

No sé decirte nada más pero tú debes comprender que aún estoy en el camino,

en el camino.

Pero tú siempre acuérdate de lo que un día yo escribí pensando en ti como ahora pienso.

Isso conflui para a construção de todo o enredo em que a vida doméstica e a realidade infantil estão submetidas à dinâmica social marcada pelo controle, pela exposição à ameaça da violência e ao agravamento do temor do abandono. Até que chega o momento em que o abandono é uma realidade. Matias e o irmão são deixados pelos pais com os avós. A canção aprofunda a emoção e a mensagem de que é preciso resistir e enfrentar a dor, o que é combinado à marcha musical e à interpretação carregada de emoção.

\section{REFERÊNCIAS}

ADORNO, T. W. Minima moralia - reflexões a partir da vida danificada. São Paulo: Ática, 1992.

ADORNO, T. W.; HORKHEIMER, Max. Dialética do esclarecimento: fragmentos filosóficos. Rio de Janeiro: Jorge Zahar, 1985.

BERNARDET, J-C. O que é cinema. São Paulo: Brasiliense, 1985.
BORDWELL, D. Sobre a história do estilo cinematográfico. Campinas: UNICAMP, 2008.

GARDIES, R. (org.). Compreender o cinema e as imagens. Lisboa: Edições Texto e Grafia, 2006.

KAMCHATKA. De Marcelo Piñeyro. Argentina. DVD, 2003.

ROJAS, G. A. A ditadura militar na Argentina (1976-1983): retomando algumas hipóteses frente aos relatos oficiais. Rev. Lutas Sociais, São Paulo, v. 18, n. 32, p. 163-176, 2014.

SOSA, M. Palabras para Julia. Buenos Aires: 1995. Disponível em https://www.ouvirmusica.com.br/mercedessosa/200718. Acesso em: 31 ago. 2019.

TRUFFAUT, F. O prazer dos olhos: textos sobre o cinema. Rio de Janeiro: Jorge Zahar, 2005. 